Kovács Éva

\title{
A természeti környezetre utaló településnevek változásai*
}

1. A természeti környezetre utaló településnevek külső és belső összefüggésrendszere a korábbi kutatásaim alapján (KOVÁCS É. 2020) nagyfokú stabilitást mutat: nemcsak a névrendszer egészében mutatkozik állandóság, hanem a belső szerkezeti típusainak időbeli viszonyait is a kiegyenlítettség jellemzi.

Jelen tanulmányban azt vizsgálom, hogy milyen mértékben érintik e névtípust a településnevek jellemző nyelvi változásai. ${ }^{1}$ A fö kérdés az lehet, hogy a természeti környezetre utaló településneveket e tekintetben is a stabilitás jellemzi-e, azaz ellenállóak a (nyelvi és a mögöttük húzódó társadalmi stb.) változásokkal szemben, vagy könnyen áldozatul esnek a módosulásoknak? Az általam vizsgált 2193 korai ómagyar kori adatból álló névállományban (a forrásokat lásd KOVÁCS É. 2019: 163-164) a neveknek mindössze az 5\%-a (105 név) esett át valamilyen szerkezeti változáson. Úgy tünik, ez a névtípus alacsony szintü változási érzékenységét mutatja, mivel például a régi Baranya megye településneveit vizsgálva TÓTH VALÉRIA azt tapasztalta, hogy ott a nevek 44\%-a változott meg valamilyen módon. Bihar megye esetében a 16. század második felében meglévő településneveknek mintegy egy ötöd részét érintette szerkezeti változás (HOFFMANN-RÁCZTÓTH V. 2018: 379). A korai ómagyar kor időhatárait kitágítva a természeti környezetre utaló településnevek változásait érintő további 57 esetet tudtam regisztrálni (ehhez alapul TÓTH VALÉRIA fent említett változástipológiai munkájának a példái szolgáltak). E változások belső arányait mutatja az 1. ábra (a statisztikában a korai ómagyar kor utáni változások is szerepelnek). ${ }^{2}$

\footnotetext{
* A tanulmány az MTA-DE Magyar Nyelv- és Névtörténeti Kutatócsoport programja keretében és az NKFI 128270. számú pályázat támogatásával készült.

${ }^{1}$ A településneveket érintő változásokat a TÓTH VALÉRIA által definiált értelemben használom (2008).

${ }^{2}$ Az ábra a bizonytalanul besorolható szinkrón névváltozatok adatait nem tartalmazza (ezekről részletesebben lásd a 2.2. pont alatt): pl. Érd ([1243]: Erdu, v., Gy. 4: 570, Pest vm.) Érdi (1243: Erdi, Gy. 4: 570), Szurdok (1326>1408: Zurdok, p., Gy. 4: 128, Máramaros vm.) Szurdoki (1326: Zurduky, t., Gy. 4: 128), Farkasföld (1324/1392: Farkasfeld, Gy. 2: 620, Györ vm.) Farkasfölde (1324/1361: Farkasfeulde, Gy. 2: 620).
} 




- kiegészülés

- ellipszis

* névelem $>$ névrész csere

" névrész $>$ névelem csere

- névrészcsere

- bővülés

- redukció

- névelemcsere

- reszemantizáció

- transzszemantizáció

- névcsere

- névosztódás

" névösszevonódás

1. ábra. A természeti környezetre utaló településnevek változásai

2. Jól láthatjuk, hogy e névtípus körében leginkább a név alakját érintő változások jellemzőek. Ezek a változások érinthetik a név funkcionális-szemantikai szerkezetét, ebben az esetben a névrészek változásáról beszélhetünk; illetve módosíthatják a név lexikális-morfológiai szerkezetét, vagyis a névelemek szintjét.

2.1. A természeti környezetre utaló településnevek egynegyede $(25,5 \%)$ esett át szintaktikai szerkezetet (azaz nemcsak a lexikális-morfológiai, hanem a funkcionális-szemantikai szerkezetét is) érintő változáson.

Ezen belül a településneveknek 15\%-a ment át a kiegészülésnek nevezett folyamaton, vagyis gazdagodott funkcionális szerepü névrésszel: földrajzi köznévi utótaggal vagy jelzői előtaggal.

A más településnév-típusokban meglehetősen gyakori jelzői szerepü névrészszel való kiegészülés (TóTH V. 2008: 66-70) a természeti névből alakult településnevek körében jóval ritkább (4\%). A változás során létrejött minőségjelzős szerkezet első névrésze elsősorban a település valamilyen sajátosságának a kifejezésére szolgál: Büked (1208/1395: Bucchid, t. Bucehid, t., Gy. 1: 714, Bodrog vm.) > Kerekbüked (1347: Kerekbeuked, p., Cs. 2: 195), Mohi (1295: Muhy, Gy. 1: 462, Bars vm.) > Árkosmohi (1325>1416: Arkusmohy, p., Gy. 1: 462), Nádasd ([1268 k.]: Nadasth, Gy. 1: 344, Baranya vm.) > Poklosnádasd (1348/1358: Poklusnadasd, v., KMHsz. 1: 225), Somlyó (1257 [0: 1259]/1390/1494: Somlyo, Gy. 3: 519, Kraszna vm.) > Vatasomlyója (1251 [0: 1258]//1390/1494: Wathasomlyowa, p., Gy. 3: 519), Somlyó (1277: Sumlow, Gy. 3: 493, Krassó vm.) > Érdsomlyója ([1284]/1439: Erdsumlwa Erdsumluwa, Gy. 3: 493). A Szentbenedekharaszti (1342: Zenbeneduk Harazthy, p., KMHsz. 1: 256, Bodrog vm. < 1333: Ha- 
razthi, p., Gy. 1: 719) településnév előtagja talán a védőszent tiszteletére emelt templomra utal.

A változáson átesett természeti környezetre utaló településnevek leginkább (11\%-ukat érintően) 'település' jelentésü földrajzi köznévi utótaggal egészültek ki. E földrajzi köznév lehetett a falva: Erdö (1221/1550: Nic. de v. Erdei, Gy. 1: 77, Abaúj vm.) > Erdöfalva (1272>1344: Erdeufalua, Gy. 1: 77), Harsány ([+1235]/1350/1404: Horzan, v., Gy. 1: 313, Baranya vm.) > Harsányfalva (1313: Harsaanfolwa, t., Gy. 1: 313), Tenger (1355: Tengur, Cs. 1: 219, Abaúj vm.) > Tengerfalva (1418: Thengerfalva, TóTH V. 2008: 72), Vadas (1227: Wodos, t., Cs. 3: 634, Sopron vm.) > Vadasfalva (1280: Vadosfolua, t., Cs. 3: 634); a telek telke: Erdö (1215/5150: Erdev, Gy. 3: 90, Heves vm.)> Erdötelek (1322: Erdeutheluk, Cs. 1: 61), Szék (1284: Zeg, t., Gy. 3: 454, Komárom vm.) > Széktelke (1314: Zektheleku, t., Gy. 3: 454), Szilas (1221/1550: Scilos, v., NÉMETH 1997: 182, Szabolcs vm.) > Szilastelke (1427: Zylostheleke, pr., NÉMETH 1997: 182), Várvize (1327/1469: Warvysy, Gy. 1: 690, Bihar vm.) > Várviztelke (1406: Waruiztheleke, TÓTH V. 2008: 87); az egyház(a): Büked (1208/1395: Bucchid, t. Bucehid, t., Gy. 1: 714, Bodrog vm.) > Bükedegyháza (1341: Bukedeghaza, p., Gy. 1: 714), Mák ([1278]/1278: Mak, Gy. 3: 114, Heves vm.) > Mákegyháza (1456: Maakeghaza, TóTH V. 2008: 73), Homorog (1214/1550: Humuroc, Gy. 1: 626, Bihar vm.) > Homorogegyház (1516: Homrokeghaz, TóтH V. 2008: 76); a monostor(a): Almás (1234 k./XV.: Almas, t., v., Gy. 1: 593, Bihar vm.) > Almásmonostora ([1291-94]: Almasmunustura, Gy. 1: 593), Sár (1264/1294: Sar, Gy. 3: 130, Heves vm.) > Sármonostora (1339: Saarmonostora, Gy. 3: 130), a lak: Tós (+1194/[1230 k.]: Thous, pr., Gy. 1: 813, Borsod vm.) > Tóslak $(+1237 /$ [1237-42]: Thovsloch, v., Gy. 1: 813); a szállás: Árok (1301: Aruk, Gy. 3: 67, Heves vm.) > Árokszállás (1396: Arukzallas, TóTH V. 2008: 72); a fö"3: Hagymás ([1270-72]>1372: Hagmas, Gy. 3: 553, Küküllő vm.) > Hagymásfó (1301/1560/ XVIII.: Hagymásfew, Gy. 3: 553), Szelnice (1256>1391: Zelniche, v., Gy. 4: 95, Liptó vm.) > Szelnicefö (1391: Zelenchefeu, Gy. 4: 95), Tepla (1340: Dopla, То́тн V. 2008: 73-74, 116, Bars vm.) > Teplafö (1388: Theplafew, То́тн V. 2008: 74, 116). A lexikális településnév-formánssal való kiegészülés e névtípust strukturális szempontból közelíti más településnév-típusokhoz. A fajtajelölő névrész megjelenése pedig elkülöníthetővé teszi e neveket a velük alakilag megegyező - és az adott település környezetében esetleg valóságosan is létező — természeti objektumokat (hegyeket, erdőket, vizeket stb.) jelölő nevektől.

\footnotetext{
${ }^{3}$ TÓTH VALÉRIA véleménye szerint a fö utótagú településnevek egy részében ez a névrész 'egy adott vízfolyás forrásánál lévő település' jelentésű másodlagos településnév-formánsként tünik fel (2008: 182-187).
} 
Az általam vizsgált névállományban szereplő nevek 5\%-ában olyan változás következett be, amelynek során egy nem névrésznyi szerepủ nyelvi elemet funkcionális szerepủ névrész váltott fel. Ezt a változási formát az előző típusként említett folyamathoz hasonlóvá teszi az a körülmény, hogy itt is lexikális helynévformáns kapcsolódik a névhez. A változást ugyanazok az okok idézhették elö, mint amiket a kiegészülésnél említettünk. A névelem > névrész típusú változások között említhetjük az Egerd ([1295-1299]: Egurd, Gy. 3: 552, Küküllő vm.) > Egervár (1347: Egurwar, TóTH V. 2008: 89-90), Hodosd ([1177]>1405: Hvdust, Gy. 1: 178, Arad vm.) > Hodosmonostora (1293: Hudusmonostura, t., Gy. 1: 178), Ökörd (1259: Vkurd, t., Gy. 4: 535, Pest vm.) > Ökörtelek (1352: Vkurteluk, p., Gy. 4: 535), Kereki (1327/1335: Kereky, Gy. 1: 224, Bács vm.) > Kerekegyház (1459: Kerekeghaz, Tótн V. 2008: 21, 89), Szegi (1274: Zygy, p., Cs. 3: 103, Zala vm.) > Szegfalu (1329: Zegfalw, p., Cs. 3: 103), Mohostó (1341: Mohostow, Cs. 1: 521, Szabolcs vm.) > Mohostelek (1378: Mohosthelek, NÉMETH 1997: 521) településneveket.

Jóval kisebb szerepe volt e névtípusban a fenti folyamattal ellentétes irányú változásnak, a névrész > névelem cserének (1,5\%): Komlóstelek (1404: Komlostelek, Cs. 1: 354, Zemplén vm.) > Komlóska (1773: Komloska, Tóтн V. 2008: 93), Nyírtelek (1300: Nyirtelek, TóTH V. 2008: 93, Ugocsa vm.) > Nyíri (1322: Nyry, Tо́тн V. 2008: 93).

A fentebb tárgyalt kiegészüléssel ellentétes irányú változás, az ellipszis, azaz funkcionális szerepü névrész — itt minden esetben a földrajzi köznévi utótag elmaradása ugyancsak kevésbé jellemzi $(1,5 \%)$ a természeti környezetre utaló településneveket: Dióstelek (1330: Gyosteluk, p., KMHsz. 1: 83, Bihar vm.) > Diós (1342: Gyoos, p., KMHsz. 1: 83), Széktelek (1228/1305/1361: Sretteluk [o: Scecteluk], Gy. 3: 454, Komárom vm.) > Szék (1247/1252//1592: Scek, Gy. 3: 454).

Mindössze néhány településnevet (2,5\%) érint a funkcionális szerepű névrészek cseréje is. A második, fajtajelölő szerepű névrész cseréje történt meg az Árpádfölde ([1332 k.]>1412: Arpadfelde, Gy. 3: 404, Komárom vm.) > Árpatelek (1415: Arpatelek, TóTH V. 2008: 145), Sárvár (1250: Sarwar, NÉMETH 2008: 258-259, Szatmár vm.) > Sármonostora (1331/1331: Sarmonustra, NÉMETH 2008: 258-259), Tengerfalva (1418: Thengerfalva, Cs. 1: 219, Abaúj vm.) > Tengerlaka (1420: Tengerlaka, Cs. 1: 219) településnevekben. A Füzéralja (13325/PR.: Fizeralia, Gy. 1: 82, Abaúj vm.) > Váralja (1389: Waralya, Cs. 1: 207) esetben pedig a birtokos jelzői előtag cseréjét láthatjuk.

2.2. A változáson átment településnevek közel kétharmad részénél $(58,5 \%)$ a névtest lexikális-morfológiai szerkezetének a módosulását figyelhetjük meg: a névelemnyi növekedés (bővülés), illetve a csökkenés (redukció) módosítja leginkább a természeti környezetre utaló településnevek szerkezetét. 
A képzőmorfémával történő bővülés a nevek 26\%-át érinti. A leggyakoribb képző a -d: Agár (1193: Agar, FNESz., Fejér vm.) > Agárd (1448: Agard, TóTH V. 2008: 122), Árpa (+1214/1334: Arpa, v., Gy. 1: 595, Bihar vm.) > Árpád (1326: Arpad, p., v., Gy. 1: 595), Diós (1330: Gyous, p., Gy. 1: 854, Csanád vm.) > Diósd (1331: Gyosd, p., Gy. 1: 854), Farkas (1113: Forcas, v., Gy. 4: 383, Nyitra vm.) > Farkasd (+1278/[XIV.]: Farkasd, p., Gy. 4: 383), Harsány ([+1235]/1350/1404: Horzan, v., Gy. 1: 313, Baranya vm.) > Harsánd (1339: Harsand, Cs. 2: 462), Hodos ([1291-94]: Hudus, Gy. 1: 625, Bihar vm.) > Hodosd (1310/1338: t. Hudust, Gy. 1: 625), Homorog (*1273/1392/1477: Homrok, Gy. 1: 626, Bihar vm.) > Homorogd (1332-7/PR.: Humrugd, v., Gy. 1: 626), Kerecseny (1261/1271: Kerechen, Gy. 3: 107, Heves vm.) > Kerecsend (1549: Kerecyend, FNESz.), Komló (1256/410: Complov, v., Gy. 1: 328, Baranya vm.) $>$ Komlód (1321: Komlod, v., Gy. 1: 328), Kökényes (1274: Kukynus, KocÁN 2017: 93, Ugocsa vm.) > Kökényesd (+1294/1550: Kökönyösd, KOCÁN 2017: 93), Köves (1255: Kues, Gy. 3: 110, Heves vm.) > Kövesd (1321/1323/1335: Kwesd, Gy. 3: 110), Somos (1497: Zomoss, TóTH V. 2008: 122, Torda vm.) > Somosd (1506: Somosd, TótH V. 2008: 122), Szamár (1208: Samar, v., Cs. 4: 210, Trencsén vm.) > Szamárd (1245: Zamard, v., Cs. 4: 211), Ürög (1267: Irg, t., Gy. 1: 222, Bács vm.) > Ürögd (1350: Irugd, Cs. 2: 152).

Az -s képzőt találjuk meg az Alma (1211/1252: Alma, Gy. 1: 270, Baranya vm.) > Almás (1338: Almas, Gy. 1: 270), Gyümölcsény (1227/1250//1779: Gemelchen, t., Gy. 3: 510, Kraszna vm.) > Gyümölcsénes (1342: Gumulchenus, Gy. 3: 510), Körtvély (1208/1359: Kurtuel, v., Gy. 4: 155, Moson vm.) > Körtvélyes ([1273-90]: Curtueles, v., Gy. 4: 155), Méh (1219/1550: Meh, v., Gy. 1: 510, Békés vm.) > Méhes (1221/1550: Mehes, Gy. 1: 510), Töke (1340 k./1383//1573: Theuke, Gy. 2: 639, Györ vm.) > Tökés (1550/1573: Thewkes, Gy. 2: 639) településnevekben.

Az -i képző kapcsolódott az Ér (*1214/1550: Her, pr., Gy. 1: 615, Bihar vm.) $>$ Éri (1326: Eery, p., Gy. 1: 615), Parlag (1330: Parlag, p., Gy. 3: 231, Hont vm.) > Parlagi (1332: Parlagy, p., Gy. 3: 231), Somogy (1323: Somug, Gy. 1: 140, Abaúj vm.) > Somogyi (1359: Somogyi, Cs. 1: 217) nevekhez, de összetett név előtagja is bővült ezzel az elemmel: Nyirtelek (1300>1417: Nyrteluk, KOCÁN 2017: 94, Ugocsa vm.) > Nyiritelek (1300/1805: Nyritelek, t., KOCÁN 2017: 94), Túrterebes (1321: Turterebes, KocÁN 2017: 95, Ugocsa vm.) > Túriterebes (1321/1324: Turiterebes, KOCÁN 2017: 96; vö. TóTH V. 2008: 120).

Ritkábban és láthatóan jóval később járult a településnevekhez a -ka/-ke képző: Eperjes (1438: Eperjes, Cs. 1: 513, Szabolcs vm.) > Eperjeske (1773: Eperjeske, TóTH V. 2008: 125), Mogyorós (1363: Monyoros, Cs. 1: 357, Zemplén vm.) > Mogyoróska (1773: Mogyoroska, TóTH V. 2008: 125), Nádas (1600: Nadas, Torna vm.) > Nádaska (1773: Nadaska, TóTH V. 2008: 125). 
A bővülés birtokos személyjellel is végbemehetett: Arok (1301: Arok, Gy. 3: 40, 67, Heves vm.) > Árka (1302: Arka, Gy. 3: 67), Farkaskorhi (1296/XV.: Forkoskorhy, p., Gy. 1: 783, Borsod vm.) > Farkaskorhija (1296: Forkoskurhya, t., Gy. 1: 783), Libánpatak (1552: Lybanpathak, TóтH V. 2008: 130, Bihar vm.) > Libánpataka (1580: Libanpataka, TÓTH V. 2008: 130), Sólyomtelek (1331/1334: Solumtelek, Gy. 3: 131, Heves vm.) > Sólyomtelke (1475: Solyomtheleke, TóTH V. 2008: 128), Szárazpatak (1425: Zarazpatak, Ugocsa vm.) > Szárazpataka (1430: Sarospathaka, TóTH V. 2008: 130).

Lexémányi névelemmel gyarapodtak a Boldva ([1295 k.]: p. et castr. Boldua, Gy. 1: 70, Abaúj vm.) > Boldvakö (1300: Bolduaku, Gy. 1: 70), Divény (1253: Dyun, t, Gy. 4: 392, Nyitra vm.) > Divénykö (1275: Dyvenkuy, Gy. 4: 392), Füzegy ([1093]: Fizeg, pr., Gy. 3: 416, Komárom vm.) > Füzegytö (1216 P./1225 k.: Fuzigteu, Gy. 3: 416), Hangony (1214: Hongun, pr., Gy. 2: 503, Gömör vm.) > Hangonyvölgye (1327: Hangunuulge, p., Gy. 2: 503), Mezöpetri (1316: Mezeupetri, Szatmár vm.) > Mezöszentpetri (1399: Mewzewzenthpetery, TóTH V. 2008: 118) településnevek.

A fentiekből kitünik, hogy szerencsés esetben a változásokat az oklevelek megfelelően, olykor gazdag névanyaggal dokumentálják, sokszor azonban a változás irányát igen nehéz meghatározni. A szinkrón névváltozatok fejlődési vonalának megrajzolását az alaki variánsok kis időbeli eltéréssel történő felbukkanása még inkább megnehezíti, és gyakran keresztező változási folyamatok befolyásoló hatásával is számolnunk kell (vö. TóTH V. 2008: 58). A későbbi-mai formák egyöntetüsége azonban jó néhány esetben egyértelmüvé teszi a változás irányának meghatározását.

Érdemes számolnunk azonban emellett azzal a körülménnyel is, hogy a képzők akár már a településnevek alapjául szolgáló természeti nevekhez is hozzájárulhattak. A korai ómagyar korban például a folyóvíznevek 9,5\%-a alakult helynévképzővel (pl. Almás: 1009/+1205-35//1404: Almas, Kövesd: 1303: Kuesd, vö. GYÖRFFY E. 2011: 113-114), és a hegynevek körében is előfordulnak képzős formák (pl. Kövesd: 1055: cuesti, Nádasd: 1389: Nadasd, vö. RESZEGI 2011: 152, 156). Figyelembe kell vennünk továbbá azt is, hogy a természeti nevek körében is jellemzőek a szerkezeti változások, többek között például az itt tárgyalt bővülésre is találunk példákat (a folyónevek változásai között lásd GYÖRFFY E. 2011: 124-132, a hegynevekre RESZEGI 2011: 166-169). Ilyen esetekben tehát többféle változási folyamattal is számolhatunk: az Alma $>$ Almás esetében ez például a következő lehetőségeket jelenti: 1. (alma növénynév >) Alma víznév > Almás víznév (bővülés) $>$ Almás településnév (metonímia); 2. Alma víznév $>$ Alma településnév (metonímia) $>$ Almás településnév (bővülés). Azt tehát, hogy a képzővel való bővülés mint névváltozási folyamat a településnevek vagy az ehhez előzményül szolgáló természeti nevek körében következett-e be, nehéz (olykor nem is 
lehetséges) eldönteni. Ha a településnevek alaki változását tekintve e csoportban hozzuk is elő a fenti Füzegy > Füzegytö, Hangony > Hangonyvölgye változásokat, a folyamatban részt vevő tő és völgye lexéma jelentése alapján aligha lehet kérdéses, hogy itt a két névforma mögött a természeti nevek kettőssége húzódik meg, s magában a településnévben ezek közül vagy az egyik vagy a másik variáns jelenik meg.

A változást elszenvedö településnevek 19,5\%-ában névelemnyi csökkenést, azaz redukciót figyelhetünk meg, amely többnyire képzőmorféma elhagyásával valósult meg: Fertöd (1234: Ferteud, v., Cs. 3: 608, Sopron vm.) > Fertö (1265: Ferteu, v., Cs. 3: 608), Füzesd ([1292-97]: Fyzesth, Gy. 1: 304, Baranya vm.) > Füzes (1315: Fyzess, Gy. 1: 304), Homrogd (1256: Humurugd, Gy. 1: 91-92, Abaúj vm. $)>$ Homrog $(* 1320>$ XIX.?: Homorogh, Gy. 1: 91), Monyorósd (1270: Monorosd, Cs. 2: 777, Vas vm.) > Monyorós (1295: Monorous, p., Cs. 2:777), Nádasd (1. [1268 k.]: Nadasth, Gy. 1: 344, Baranya vm.; 2. +1244: Nadasd, Gy. 3: 220, Hont vm.; 3. 1428: Nadasd, Cs. 1: 240, Torna vm.) > Nádas (1. 13325/PR.: Nadas, Gy. 1: 344, Baranya vm.; 2. *+1245/1270: Nados, t., Gy. 3: 220, Hont vm.; 3. 1600: Nadas, TóTH V. 2008: 137, Torna vm.); Haraszti (1342: Harazty, p., KMHsz. 1: 122, Baranya vm.) > Haraszt (1347: Harazth, KMHsz. 1: 122), Kereki (1220/1550: Kerequi, v., Gy. 1: 632, Bihar vm.) > Kerek (1284: Kerek, Gy. 1: 632), Széki (1236: Zeki, t., Gy. 3: 454, Komárom vm.) > Szék (1460: Zeek, p., Gy. 3: 453), Szili (1281>1402: Zyly, t., Gy. 4: 469, Nyitra vm.) > Szil (1332/PR.: Zel, Gy. 4: 469); Szilas (1374: Zylas, TóTH V. 2008: 102, Bihar vm.) > Szil (1475: Zyl, TóTH V. 2008: 102); Kórógy (*1323: Chorog, Gy. 1: 635, Bihar vm.) > Kóró (1335: Chorow, KMHsz. 1: 160) és talán a Somogyon (1317: Sumugun, p., Gy. 3: 559, Küküllő vm.) > Somogy (1325/349: Symyg, t., p., Gy. 3: 559) név esetében.

Az összetett nevek előtagjában is előfordulhat a képző elmaradása: Csíkiszentgyörgy (1456: Chijkijzenthgewrgh, TÓTH V. 2008: 68, Csíkszék) > Csíkszentgyörgy (1531: Chykzenthgewrgh, То́тн V. 2008: 68), Szilibács (1263/1466/1476: Zyli Bach, Gy. 1: 235, Bács vm.) > Szilbács (1267: Scylbach, Gy. 1: 235).

A birtokos személyjel redukcióját láthatjuk a Bátatöve $(+1015 /+1158 / / 1403 /$ PR.: Batatue, v., Gy. 1: 281, Baranya vm.) > Bátatö (1346, 1347: Bathathew, p., Cs. 2: 471), Csabkuta (1330: Chobkuta, Gy. 1: 292, Baranya vm.) > Csabkút (1341: Chapkwth, v., Gy. 1: 292), Hegymege (1272: Higmugi, Gy. 1: 775, Borsod vm.) > Hegymeg (1332-5/PR.: Hedimeg, Gy. 1: 776), Péterréve $(+1092 /+1274 /$ 1399: Peterreue, v., DHA. 285, Bács vm.) > Péterrév (+1247/+1284/1572: Peturreu, Gy. 1: 230), Szentjánoshegye (1435: Zenthjanoshegye, TóтH V. 2008: 109, erdélyi Fehér vm.) > Szentjánoshegy (1808: Szent-Jánoshegy, TóTH V. 2008: 109), Szentgyörgyvölgye (1399: Zenth-gywrguelge, TóTH V. 2008: 108, Zala vm.) > Szentgyörgyvölgy (1412: Zenthgergwelg, TóTH V. 2008: 108) településnevekben. Itt említhetjük talán a Székáspataka Székáspatak (1357/1358: 
Zekaspataka, p. Zykaspatak, p., Gy. 3: 495, Krassó vm.) névváltozatokat is. E szinkrón nyelvi variánsok meglétét maguk az oklevelek is bizonyítják, történeti változásuk irányát viszont nem egyszerü meghatározni. A fentieknél is bizonytalanabbak az alábbi esetek: Érd ([1243]: Erdu, v., Gy. 4: 570, Pest vm.) Érdi (1243: Erdi, Gy. 4: 570), Szurdok (1326>1408: Zurdok, p., Gy. 4: 128, Máramaros vm.) Szurdoki (1326: Zurduky, t., Gy. 4: 128), Farkasföld (1324/1392: Farkasfeld, Gy. 2: 620, Györ vm.) Farkasfölde (1324/1361: Farkasfeulde, Gy. 2: 620).

A településnevek lexikális elemei szintén elmaradhatnak a nevekben. A kétrészes természeti nevekből metonimikus névátvitellel alakult s így egyrészesnek minősülő településneveknek mind az első, mind pedig a második lexémája kieshet a névböl: Káváskút (*1251/1328/1374: Nic. f. Mych-is de Kauaskuty, Gy. 1: 322, Baranya vm.) > Kávás (*1330: Kawas, Gy. 1: 322), Hódostó (1219/1550: Hodosto, v., NÉMETH 2008: 113-114, Szatmár vm.) > Hódos (1328: Hudus, NÉMETH 2008: 114), Kengyelszeg (1341: Kengelzegh, KMHsz. 1: 149, Bihar vm.) > Kengyel (1348: Kengel, KMHsz. 1: 149), Örvényesligete (1336: Wrwenusligethe, То́тH V. 2008: 100, Bihar vm.) > Örvényes (1360: Ewrwenes, Tо́тн V. 2008: 100), Sósújfalu (1748: Sós Újfalu, TóтH V. 2008: 99, Ugocsa vm.) > Sósfalu (1907: Sósfalu, Tóтн V. 2008: 99), Szárazpatak (1425: Zarazpatak, Тóтн V. 2008: 100, Ugocsa vm.) > Patak (1459: Pathak, Cs. 1: 435), Erdöárka ([1291]/XVI.: Erdewarka, t., Gy. 3: 67, Heves vm.) > Árok (1301: Aruk, p., Gy. 3: 67), Galambláza (1325: Golomblaza, Cs. 1: 390, 394, Ung vm.) > Láz (1337: Laaz, Cs. 1: 390, 394).

A nevek 13\%-ában névelemcsere, elsősorban képzőcsere történt. Az általam feldolgozott névállományban — és általában a településnevek körében is (vö. Tо́тH V. 2008: 135-136) — leggyakoribbnak az elsődlegesen -gy képzővel álló településnév - $d$ képzősre cserélődése tünik: Debregy (1255: Debregy, Gy. 1: 76, Abaúj vm.) > Debröd (1427: Debred, Cs. 1: 205), Kékegy ([1290 k.]: Keykug, Gy. 1: 323, Baranya vm.) > Kékes (1387: Tothkekes, TóTH V. 2008: 134-135)> Kékesd (1808: Kékesd, vö. TóTH V. 2008: 135), Kórógy (1344: Korogh, p., NÉMETH 2008: 154, Szatmár vm.) > Kóród (1345: Korod, p., NÉMETH 2008: 154), Nyárágy (1238/1377: Narrag, t., Gy. 1: 793, Borsod vm.) > Nyárád (1317: Narad, v., Gy. 1: 793), Nyárágy Nyárasd (1385: Narag que nunc Narasd nominaretur, TóтH V. 2008: 136), Nyüvegy (1. 1229: Nywg, Gy. 1: 464, Bars vm.; 2. 1213/1550: Neueg, Gy. 1: 647, Bihar vm.) > Nyüved (1. 1418: Newyd, Bars vm., TóтH V. 2008: 135; 2. 1332-7/PR.: Niued, Gy. 1: 647, Bihar vm.), s talán itt említhetjük a Diós (1363: Dius, Cs. 1: 27, Pest vm.) > Diógy Diód (1417: Gyogh Gyod, TóTH V. 2008: 134) neveket is. Fordított irányú (-d $>-g y)$ változásra szintén találunk példát: Nyárád (+1093/1404: Narad, DHA. 294, Baranya vm.) > Nyárágy (1270: Narag, Gy. 1: 349), Sasad (1236/1286//1504: Sassard, Gy. 4: 694, Pilis vm.) > Sáságy (1291: Sassag, Gy. 4: 694). A változási irány 
meghatározása azonban — ahogyan az előző típusoknál is láthattuk — nem minden esetben egyértelmü. Az adatok alapján sokszor a nevek valós használata, illetve használati köre és ideje is nehezen állapítható meg (vö. TóTH V. 2008: 137138).

Más képzők cserélödése ritkábban fordul elö: Kövesd (1323: Kwesd, Gy. 2: 518, Gömör vm.) > Kövecses (1343>1351: Kueches, Gy. 2: 518), Mogyoród Mogyorós (1269/1294: Munorod Munoros, Gy. 2: 299, Esztergom vm.), Örvénd (1282: Vluend, Gy. 1: 649, Bihar vm.) > Örvényes (1360: Ewruenes, Cs. 1: 599).

A névelemcsere mint változás ritkábban a településnév lexémányi összetevőjét is érintheti: Hévszamos (1448: Hewzamus, FNESz., Kolozs vm.) > Melegszamos (1733: Meleg Szamos, TóTH V. 2008: 131), illetve Verespart (1322: Wrusporth, p., Gy. 1: 877, Csanád vm.) > Veresmart (1330: Verusmorth, Gy. 1: 877). A Hidegséd (1291: Hydegsed, Cs. 2: 756, Vas vm.) > Hidegkút (1346: Hidegh$k w t$, vö. TÓTH V. 2008: 133) változás pedig valójában eltérő helyfajtán alapuló névadást mutat: a folyóvíz, illetve forrás neve szolgált — hasonló szemantikával - a településnevek metonimikus alapjául. Egy esetben pedig lexémányi névelem és képzőmorféma cseréjét figyelhetjük meg: Almatöve $(+1183 / 1326 / 1363$ : Almatui, Gy. 1: 270, Baranya vm.) > Almás (1338: Almas, Gy. 1: 270).

2.3. A fent említett szabályos alaki változások mellett szabálytalan alakszerkezeti módosulásokat szintén találhatunk a természeti környezetre utaló településnevek között, az arányuk azonban nagyon csekély (2\%). A Turóc megyei elsődleges, lexikális szempontból nem áttetsző, szláv eredetü Zsábokrék (1282: Zabakrek, FNEsz.) névformából a nyelvérzék Zsámbokrét (1292: Sabochret, MÁLYUSZ 1922/2014: 79) alakot formált. E módosulás, a reszemantizáció eredményeképpen a névalak lexikális-morfológiai síkon azonosíthatóságot és funkcionális-szemantikai szempontból pedig valamilyen motivációt nyert (a folyamathoz lásd TóTH V. 2008: 165-178). A világos lexikai és szemantikai szerkezetü Kökút (1263/XVI.: Kewkwth, Veszprém vm.) a transzszemantizációs változás révén szintén jól azonosítható, hangalakilag az eredeti névformához közel álló Kékkúttá (1569: kek kwth, FNESz.) alakult (vö. TÓTH V. 2008: 179).

2.4. A természeti környezetre utaló településnevek egy része teljes változáson, azaz névcserén ment keresztül. A Tihanyi alapítólevélbeli Disznó (1055: gisnav) megnevezés az adományozást követően az új birtokosra utaló Apáti névformával cserélődött fel (vö. HOFFMANN 2010: 98-99). Egy ideig a két névalak párhuzamosan élt egymás mellett (1267/1296: Gesnov vel Apathy, Cs. 2: 587), majd az utóbbi kiszorította az elsődleges alakot (1275, 1536: Apaty, Cs. 2: 587). A természeti környezetre utaló településneveket ehhez hasonlóan a humán vagy épített környezetre utaló nevek váltották fel: Erdö (1243/1335/XVII.: Erdö, Gy. 2: 482, Gömör vm.) Erdös (1243/1335: Erdes, p., Gy. 2: 482) > Ardó (1318: Ordou, v., 
Gy. 2: 482), Erdöfalva (1272>1344: Erdeufalua, Gy. 1: 77, Abaúj vm.) > Didic (1329/1406/1489: Dydych, t., Gy. 1: 77), Ronka (1216: Runka, Gy. 3: 450, Komárom vm.) > Ásványtö (1226: Asuantheu, Gy. 3: 450), Tyukod (1235-70>1331: Tyukud, p., Gy. 3: 107, Heves vm.) > Kerekudvar (1324/1343: Keregwduar Kerekwdwar, Gy. 3: 107). A névalakok egyidejü használatát mutatják a következő példák: Hagymás Désfalva ([1270-72]>1372: Hagmas alio nomine Desfolua, Gy. 3: 551, 553, Küküllő vm.), Örhalom (*1310>1358: Herholm, Gy. 2: 80, Doboka vm.) Márkháza (1318: Markhaza, v.; 1348: Eurholm ... alio nomine Markhaza, Gy. 2: 80). A névcsere azonban hasonló szemléleti alapon keletkezett névformák között is végbemehetett: Keltekö (+1158/1496: Kultekw, t., Gy. 3: 464, Komárom vm.) > Zsitvatö (1271/1360/1361>1496: Sythwathew, p., Gy. 3: 465), Gyümölcsényes (1342: Gumulchenus, Gy. 3: 510, Kraszna vm.) Borzás (1342: Bozyas, p., Gy. 3: 510).

A szinonim viszony azonban nem minden esetben eredményezett közvetlenül névcserét (vö. TÓTH V. 2008: 63). A Garamszentbenedeki alapítólevél Rikács(i)ártánd (1075/+1124/+1217: RikachiArtand, SzÖKE 2015: 190, Bihar vm.) összetett névalakja mögött ugyanannak a helynek a két megnevezése rejlik. A legújabb kutatások ugyanis azt mutatják, hogy az oklevélírók az alapítólevél utólagos kiegészítésekor az oklevélben eredetileg szereplő Rikács név mellé illesztették az új, Artánd (+1214/1334: Artandi, [1291-94], 1332-7/PR., 1517, 1587, 1598: Artand, 1332-7/PR., 1517, 1588: Arthand, p.) megnevezést, nem pedig kicserélték azzal (vö. SzÖKE 2015: 190-191). Később azonban — ahogyan a fenti adatok is mutatják - az utóbbi névforma a település egyedüli nevévé vált.

A névcsere az itt vizsgált természeti környezetre utaló településnevek körében tehát kevésbé jellemző (6\%).

3. A természeti környezetre utaló településnevek körében a fent említett alaki változásokon túl a nevek denotatív jelentését érintő változással az esetek 4\%-ában találkozunk. A vizsgált névállományban regisztrált névösszevonódások és névosztódások hátterében elsősorban településtörténeti változások húzódtak meg. Az egykori Szurdok (1234/1243: Zurdok, Gy. 1: 150, Abaúj vm.) település a közeli Bénye (1293/1496: Benye, Gy. 1: 150) településsel összeolvadva kapta meg a közös Szurdokbénye (1326/1375: Zurdukbenye, p., Gy. 1: 149-150) nevet. Ugyanígy Harsány és Kér települések (1267: Horsan et Keer, KMHsz. 1: 124) összeolvadásával alakulhatott a Bács megyei Harsánykér (1297/1424/1783: Harsankér, p., Gy. 1: 221, 223) településnév is. A Tökésújfalu (1317>1436: Thewkeswyfalu, Gy. 1: 151, Abaúj vm.) a Tökés (1325[0: 1317-20]: Teukees, Gy. 1: 151) és az Újfalu (1317: Vyfolu, Gy. 1: 151), a Hódvásárhely (1385: Hodwasarhel, Gy. 1: 859, Csongrád vm.) pedig a Hód (1231: Houd, Gy. 1: 859) és a Vásárhely ([1282?]: Wasarhel, Gy. 1: 859) nevek összevonódásával jött létre. A természeti környezetre utaló előtagok így az új, összetett névben is ellátták ugyanezt a funkciójukat. 
Ellentétes folyamatként értelmezhetjük talán a Csalános (1330: Chalanus, p., Gy. 1: 607, Bihar vm.) > Ócsalános (1342: Ochalanus, p., Gy. 1: 607) módosulást. A névosztódással állnak összefüggésben a következő településnevek is: a Baranya megyei Árpád (1181: Arpad, Gy. 1: 271) településből Olaszárpád (1332-5/PR.: Jo. de Arpad Gallico Holas Arpad, Gy. 1: 271) néven vált ki önálló falu (KMHsz. 1: 18). A Bihar megyei Diószeg ([1278 k.]: Gyozyk, Gy. 1: 613) nevü faluból pedig Diószeghídvége ([1291-94]: Gyozeg hiduege, v., Gy. 1: 613) néven jött létre időlegesen önálló település (KMHsz. 1: 93).

4. Összegzésképpen megállapítható, hogy a természeti környezetre utaló korai ómagyar kori településnevek változási érzékenysége igen alacsony (5\%). Még kisebb aránnyal, 4\%-kal számolhatunk, ha tisztán a nyelvi okokkal magyarázható változásokat tekintjük. TÓTH VALÉRIA véleménye szerint ugyanis „a névcsere vagy a jelzővel való kiegészülés elsősorban nem nyelvi okokkal, hanem a valóság viszonyaival (pontosabban az azokban bekövetkezett változásokkal) magyarázható" (2008: 236). E névtípust a településnevek jellemző nyelvi változásai tehát kevésbé érintik, vagyis a természeti környezetre utaló településneveket e tekintetben is a kiegyenlítettség jellemzi.

\section{Irodalom}

Cs. = CsÁNKI DEZsÖ 1890-1913. Magyarország történelmi földrajza a Hunyadiak korában I-III., $V$. Budapest, Magyar Tudományos Akadémia.

FNESz. = KISS LAJOS 1988. Földrajzi nevek etimológiai szótára I-II. Negyedik, bövített és javított kiadás. Budapest, Akadémiai Kiadó.

Gy. = GYÖRFFY GYÖRGY 1963-1998. Az Arpád-kori Magyarország történeti földrajza $I-I V$. Budapest, Akadémiai Kiadó.

GYÖRFFY ERZSÉBET 2011. Korai ómagyar kori folyóviznevek. A Magyar Névarchívum Kiadványai 20. Debrecen, Debreceni Egyetemi Kiadó.

HofFMANN IsTVÁn 2010. A Tihanyi alapitólevél mint helynévtörténeti forrás. A Magyar Névarchívum Kiadványai 16. Debrecen, Debreceni Egyetemi Kiadó.

HOFFMANN ISTVÁN-RÁCZ ANITA-TÓTH VALÉRIA 2018. Régi magyar helynévadás. A korai ómagyar kor helynevei mint a magyar nyelvtörténet forrásai. Budapest, Gondolat Kiadó.

KMHsz. $=$ HOFFMANN IsTVÁN szerk. 2005. Korai magyar helynévszótár 1000-1350. I. Abaúj-Csongrád vármegye. A Magyar Névarchívum Kiadványai 10. Debrecen, Debreceni Egyetem Magyar Nyelvtudományi Tanszéke.

KoCÁN BÉLA 2017. Helynévtörténeti vizsgálatok a régi Ugocsa megyében. A Magyar Névarchívum Kiadványai 45. Debrecen, Debreceni Egyetemi Kiadó.

KovÁCs ÉVA 2019. A természeti környezetre utaló településnevek strukturális kérdései. Helynévtörténeti Tanulmányok 15: 163-178.

DOI: 10.35528/Helynevtort/15/09 
KovÁCS ÉVA 2020. A természeti környezetre utaló településnevek kronológiai viszonyai. Magyar Nyelvjárások 58: 121-132.

DOI: $10.30790 / \mathrm{mnyj} / 2020 / 06$

MÁlyusz Elemér 1922/2014. Turóc megye kialakulása. Budapest, Budavári Tudományos Társaság, 1922. Újraközlése: Historia Incognita III. sorozat, Máriabesnyő, Attraktor, 2014.

NÉMETH PÉTER 1997. A középkori Szabolcs megye települései. Nyíregyháza, Ethnica.

NÉMETH PÉTER 2008. A középkori Szatmár megye települései a XV. század elejéig.

A Nyíregyházi Jósa András Múzeum Kiadványai 60. Nyíregyháza.

RESZEGI KATALIN 2011. Hegynevek a középkori Magyarországon. A Magyar Névarchívum Kiadványai 21. Debrecen, Debreceni Egyetemi Kiadó.

SzÖKE MELINDA 2015. A garamszentbenedeki apátság alapitólevelének nyelvtörténeti vizsgálata. A Magyar Névarchívum Kiadványai 33. Debrecen, Debreceni Egyetemi Kiadó.

TÓTH VALÉRIA 2008. Településnevek változástipológiája. A Magyar Névarchívum Kiadványai 14. Debrecen, Debreceni Egyetem Magyar Nyelvtudományi Tanszéke.

\section{Changes in Settlement Names Referring to the Natural Environment}

In this paper I examine the extent to which the settlement names referring to the natural environment are influenced by changes in the linguistic subsystem of settlement names. The key question is if this name type is characterized by stability in this respect as well, i.e., if they are resistant to (linguistic and underlying social, etc.) changes, or they are prone to modification. In the examined name corpus consisting of 2,193 data from the early Old Hungarian Era, only 5\% of the names (105) went through some kind of a structural change.

Among settlement names referring to the natural environment mostly those changes are typical that affect the form of the name. In close to two thirds of the settlement names that were affected by change, we witness the modification of the lexical-morphological structure of the name body: an expansion or reduction with a name element is most likely to modify the structure of settlement names referring to the natural environment. In the Kereki (< kerek 'forest' $+-i$ formant) $>$ Kerek settlement name, for example, the $-i$ formant is abandoned. In the Árok (<árok 'ditch') $>$ Árka name we may identify the expansion of the original name with the $-a$ possessive suffix. One quarter of the settlement names referring to the natural environment experienced changes affecting the syntactic structure (i.e., also the lexical-morphological and functional-semantic structure of the name). In this case the primary names were expanded mostly with some kind of geographical common name secondary constituent meaning 'settlement': e.g., Erdö (< erdö 'forest') $>$ Erdötelek (the telek secondary constituent means 'lot, village'), Vadas

(<vad 'game' + $-s$ formant 'abundant in game') $>$ Vadasfalva (the falu $\sim$ falva secondary constituent means 'village'), etc. In the name corpus studied, other 
regular changes within this name type were less frequent, as for example, the complementation with an attribute in Mohi (< moha 'moss' $+-i$ formant) $>$ Árkosmohi (the structure of the árkos attribute: árok 'ditch' $+-s$ formant), etc.

Besides these regular formal changes, we may also find irregular structural changes among settlement names referring to the natural environment, however, their proportion is low (25 names), e.g., Kökút (<kö 'stone' + forrás 'spring') > Kékkút (< kék 'blue' + kút 'spring').

Only $6 \%$ of the settlement names referring to the natural environment went through complete changes: e.g., Disznó (< disznó 'pig') > Apáti $(<$ apát 'abbot' $+-i$ formant), Erdöfalva (< erdö 'forest' + falva 'village') $>$ Didic (toponym formed from an anthroponym), etc.

Besides the formal changes, within this name type we may also encounter changes affecting the denotative meaning of names but only in a low number (4\%). In this respect, we may mention the Szurdokbénye settlement name which was created through the merger of the names of the former settlements of Szurdok ( $<$ szurdok 'gorge, canyon') and Bénye ( $<$ formed from an anthroponym). 
